\title{
SURVEY PEMAHAMAN DAN KETERLIBATAN MAHASISWA DAN DOSEN DALAM PROGRAM KEBIJAKAN MERDEKA BELAJAR KAMPUS MERDEKA DI PROGRAM STUDI PENDIDIKAN EKONOMI FKIP UNIVERSITAS PASUNDAN
}

\author{
${ }^{1}$ Leni Maryani, ${ }^{2}$ Saiful Almujab, ${ }^{3}$ Yudho Ramafrizal, ${ }^{4}$ Veri Aryanto Sopiansah \\ ${ }^{1234}$ Pendidikan Ekonnomi Fakultas Keguruan dan Ilmu Pendidikan Universitas \\ Pasundan \\ lenimaryani@unpas.ac.id
}

\begin{abstract}
ABSTRACK
The objectives of the final report of this research are (1) to determine the understanding of students and lecturers in the Merdeka Learning policy program at the Merdeka Campus at the Economic Education Study Program, FKIP, Pasundan University; (2) to find out the involvement of students and lecturers in the Independent Learning Policy Program at the Independent Campus at the Economics Education Study Program, FKIP, Pasundan University.

The implementation method in the research program on the implementation of the Independent Learning Policy-Independent Campus (MBKM) is in the form of a population survey (total sampling) involving students, and lecturers at the Pasundan University economic education study program.

The survey results show that in general students understand the independent campus learning policy program in the economic education study program FKIP Pasundan University, this is indicated by the average student answers about each question item in the survey showing a response according to the answer indicators provided.

Some of the author's suggestions are input as a form of concern for the study program in implementing the MBKM program so that it can be even better, of course the consistency of all human resources involved is very necessary in optimizing the implementation of this MBKM activity.
\end{abstract}

Keywords: Understanding, Involvement, Policy, Independent Learning ProgramIndependent Campus

\footnotetext{
ABSTRAK

Tujuan dari laporan akhir penelitian ini, yaitu (1) untuk mengetahui pemahaman mahasiswa dan dosen dalam program kebijakan Merdeka Belajar Kampus Merdeka di Program Studi Pendidikan Ekonomi FKIP Universitas Pasundan; (2) untuk mengetahui keterlibatan Mahasiswa dan Dosen dalam Program Kebijakan Merdeka Belajar Kampus Merdeka di Program Studi Pendidikan Ekonomi FKIP Universitas Pasundan.

Metode pelaksanaan dalam program penelitian implementasi Kebijakan Merdeka Belajar-Kampus Merdeka (MBKM) yaitu berupa survey populasi (total sampling) yang melibatkan mahasiswa, dan dosen pada program studi pendidikan ekonomi Universitas Pasundan.

Hasil survey menunjukan secara umum mahasiswa memahami program kebijakan merdeka belajar kampus merdeka di program studi pendidikan ekonomi FKIP Universitas Pasundan, hal ini ditunjukan dengan rata-rata jawaban mahasiswa tentang setiap item pertanyaan dalam survey menunjukan respon sesuai dengan indikator jawaban yang disediakan.

Beberapa saran penulis masukan sebagai bentuk kepeduliian terhadap program studi dalam melaksanakan program MBKM agar bisa lebih baik lagi, tentunya konsistensi seluruh SDM yang terlibat sangat diperlukan dalam mengoptimmalkan pelaksanaan kegiatan MBKM ini.
} 
Kata Kunci: Pemahaman, Keterlibatan, Keijakan, Program Merdeka Belajar-Kampus Merdeka

\section{Pendahuluan}

Dalam menghadapi perubahan sosial, budaya, kebutuhan dunia kerja dan kemajuan teknologi yang sangat pesat, kompetensi mahasiswa harus disiapkan dan sesuai dengan kebutuhan zaman. Tren dan tuntutan kompetensi SDM abad ke 21 serta perkembangan ilmu pengetahuan dan teknologi telah mempengaruhi perubahan zaman dan menjadi faktor penting bagi perkembangan dunia pendidikan khususnya pendidikan tinggi. Link and match tidak hanya dengan dunia industri dan dunia kerja tetapi juga dengan masa depan yang dapat berubah dengan cepat. Oleh karena itu, Perguruan Tinggi dituntut untuk dapat merancang dan melaksanakan proses pembelajaran yang kreatif dan inovatif agar mahasiswa dapat mencapai pembelajaran yang mencakup aspek sikap, pengetahuan, dan keterampilan secara maksimal dan selalu relevan dengan kebutuhan zaman.

$\mathrm{Hal}$ ini selaras dengan tujuan pendidikan tinggi yang ditetapkan dalam UU No 12 tahun 2012 yang berbunyi :

Berkembangnya potensi Mahasiswa agar menjadi manusia yang beriman dan bertakwa kepada Tuhan Yang Maha Esa dan berakhlak mulia, sehat, berilmu, cakap, kreatif, mandiri, terampil, kompeten, dan berbudaya untuk kepentingan bangsa serta dihasilkannya lulusan yang menguasai cabang IImu Pengetahuan dan/atau Teknologi untuk memenuhi kepentingan nasional dan peningkatan daya saing bangsa.

Pada tahun 2020, Kementerian Pendidikan dan Kebudayaan Republik Indonesia telah mengeluarkan Kebijakan Merdeka Belajar-Kampus Merdeka (MBKM) dalam bentuk Permendikbud No 3 Tahun 2020. Kebijakan MBKM, merupakan kebijakan Menteri Pendidikan dan Kebudayaan, yang bertujuan mendorong mahasiswa menguasai berbagai keilmuan yang berguna untuk memasuki dunia kerja. Merdeka Belajar-Kampus Merdeka memberikan kesempatan bagi mahasiswa memiliki pengalaman belajar lain di luar program studinya.

Permendikbud Nomor 3 Tahun 2020 tentang Standar Nasional Pendidikan Tinggi, pada Pasal 18 disebutkan bahwa pemenuhan masa dan beban belajar bagi mahasiswa program sarjana atau sarjana terapan dapat dilaksanakan: 1) mengikuti seluruh proses pembelajaran dalam program studi pada perguruan tinggi sesuai masa dan beban belajar; dan 2) mengikuti proses pembelajaran di dalam program studi untuk memenuhi sebagian masa dan beban belajar dan sisanya mengikuti proses pembelajaran di luar program studi. Melalui Merdeka Belajar-Kampus Merdeka, mahasiswa memiliki kesempatan untuk 1 (satu) semester atau setara dengan 20 (dua puluh) sks menempuh pembelajaran di luar program studi pada Perguruan Tinggi yang sama; dan paling lama 2 (dua) semester atau setara dengan 40 (empat puluh) sks menempuh pembelajaran pada program studi yang sama di Perguruan Tinggi yang berbeda, pembelajaran pada program studi yang berbeda di Perguruan Tinggi yang berbeda; dan/atau pembelajaran di luar Perguruan Tinggi.

Merdeka Belajar-Kampus Merdeka merupakan salah satu kebijakan dari Menteri Pendidikan dan Kebudayaan. Kebijakan Merdeka Belajar-Kampus Merdeka diharapkan dapat menjadi jawaban atas tuntutan tersebut. Kebijakan tersebut dapat diartikan sebagai bentuk pemberian kebebasan secara otonom kepada lembaga 
pendidikan dan merdeka dari birokrasi yang terlalu panjang dan kebebasan bagi mahasiswa memilih program yang diinginkan (Direktorat Jenderal Pendidikan Tinggi Kemendikbud RI, 2020). Tujuan besar yang ingin dicapai oleh Kementerian Pendidikan dan Kebudayaan Riset dan Teknologi (Kemdikbud Ristek) adalah terciptanya kultur lembaga pendidikan yang otonom, tidak birokratis, dan terciptanya sistem pembelajaran yang inovatif berbasis pada peminatan dan tuntutan dunia modern. Kebijakan ini telah membuka harapan besar bagi Perguruan Tinggi untuk mampu berkembang dengan cepat dan mampu mengembangkan mutu institusi.

Otonomi perguruan tinggi seperti dimaksud merupakan harapan yang sejak dahulu disuarakan baik untuk pelaksanaan Pendidikan dan Pengajaran, Pelaksanaan Penelitian dan juga Pengabdian Pada Masyarakat. Pembelajaran dalam Merdeka Belajar-Kampus Merdeka akan memberikan tantangan serta kesempatan bagi mahasiswa untuk dapat mengembangkan kreativitas, kapasitas, kepribadian, dan kebutuhan, serta mengembangkan kemandirian dalam mencari dan menemukan pengetahuan melalui kehidupan nyata dan dinamika dalam lapangan seperti persyaratan kemampuan, interaksi sosial, kolaborasi, manajemen diri, tuntutan kinerja, target dan pencapaiannya.

Keberhasilan penyelenggaraan Merdeka Belajar-Kampus Merdeka di perguruan tinggi sangat ditentukan oleh keterlibatan dan peran serta seluruh sivitas akademika terutama peran mahasiswa dan dosen. Selain itu, mahasiswa dan dosen pun harus bisa memahami program yang ada dalam Merdeka Belajar-Kampus Merdeka. Apabila pemahaman dan keterlibatan mahasiswa dan dosen tidak optimal, maka hasil yang akan dicapainya pun tidak akan sesuai dengan tujuan dari kebijakan Merdeka Belajar-Kampus Merdeka, yaitu meningkatkan kompetensi lulusan, baik soft skills maupun hard skills, agar lebih siap dan relevan dengan kebutuhan zaman, menyiapkan lulusan sebagai pemimpin masa depan bangsa yang unggul dan berkepribadian.

Harapan dari keterlibatan dan pemahaman para mahasiswa dan dosen adalah terselenggaranya program Merdeka Belajar-Kampus Merdeka serta dapat dilaksanakan secara optimal sehingga dapat menjawab tantangan Perguruan Tinggi untuk menghasilkan lulusan yang sesuai perkembangan zaman, kemajuan IPTEK, tuntutan dunia usaha dan dunia industri, maupun dinamika masyarakat.

Berdasarkan latar belakang yang telah disampaikan di atas, maka penulis tertarik untuk melakukan penelitian laporan akhir dalam program Merdeka Belajar-Kampus Merdeka yang dilaksanakan di tingkatan program studi dengan judul "Survey Pemahaman dan Keterlibatan Mahasiswa dan Dosen dalam Program Kebijakan Merdeka Belajar Kampus Merdeka di Program Studi Pendidikan Ekonomi FKIP Universitas Pasundan".

\section{Landasan Teori}

\section{Pemahaman}

Menurut Kamus Besar Bahasa Indonesia (KBBI), pemahaman berasal dari kata paham yang artinya pengertian, pendapat, pandai dan mengerti benar. Sedangkan pemahaman itu sendiri mempunyai arti sebuah proses, cara, serta perbuatan memahami atau memahamkan. Menurut Winkel dalam Dimas (2019, hlm. 3) mengemukakan bahwa pemahaman merupakan kemampuan dasar dalam 
mendapatkan makna dan arti dari hal yang telah dipelajari. Sedangkan, Menurut Susanto (2020, hlm. 15) mengemukakan bahwa pemahaman merupakan kemampuan menjelaskan kembali, dan menarik kesimpulan dari suatu data yang dipelajari. Menurut Monica dan Fitriawati (2020, hlm. 1637) menambahkan bahwa pemahaman tidak hanya sekedar mengetahui namun dapat juga mengaplikasikan apa yang sudah dipahami. Pemahaman memiliki kedudukan penting dalam proses pembelajaran, seseorang harus mengerti betul makna dari yang telah dipelajarinya untuk nantinya ditarik kesimpulan dengan bahasa sendiri dan dapat mengimplementasikan pemahamannya dalam kehidupan dengan berbagai penerapan keadaan yang berbeda-beda.

Berdasarkan beberapa pendapat tersebut dapat disimpulkan bahwa pemahaman adalah suatu proses penting penguasaan materi yang berhubungan dengan kecerdasan seseorang dalam menarik makna dengan benar untuk dapat menerapkan kembali informasi yang didapat terhadap situasi baru lainnya.

Menurut Skemp dalam Abdurrifqi (2018, hlm. 20) menjelaskan bahwa pemahaman digolongkan menjadi dua tingkatan, yaitu:

1. Pemahaman Instrumental

Pada tingkatan ini mahasiswa mampu mengingat kembali mengenai fakta dasar, istilah, atau hal-hal yang rutin dilakukan. Indikator pada pemahaman instrumental, diantaranya:

a. Dapat menyebutkan kembali

b. Dapat menuliskan

c. Dapat mengidentifikasi

d. Dapat mengurutkan

e. Dapat memilih

f. Dapat menunjukkan

g. Dapat menyatakan

h. Dapat menghitung

2. Pemahaman Relasional

Tingkatan ini mahasiswa mampu menerapkan secara tepat pemahaman yang didapat pada situasi lainnya. Indikator pada pemahaman relasional ini, yaitu:

a. Dapat menggunakan

b. Dapat menerapkan

c. Dapat menghubungkan

d. Dapat menggeneralisasi

e. Dapat menyusun

f. Dapat mengklasifikasi

Menurut Syahraeni (2016, hlm. 14) mengemukakan bahwa pemahaman seseorang dipengaruhi oleh tingkat kecerdasan yang dimiliki, diantaranya:

1. Kecerdasan Intelektual

Intelektual merupakan kemampuan bertindak, berpikir, serta menghadapi lingkungan secara efektif dan rasional. Kecerdasan intelektual merupakan sebuah kecerdasan yang dimiliki seseorang berasal dari gen orangtua yang meliputi kemampuan dalam menalar, memecahkan masalah, dan memahami gagasan.

2. Kecerdasan Emosional 
Kecerdasan emosional adalah kecerdasan yang berada dalam diri seseorang yang mengimbangi pola piker jernih yang beriringan dengan kecerdasan intelektual. Menurut Goleman dalam Syahraeni (2016, hlm. 16) menyatakan bahwa terdapat beberapa komponen dalam kecerdasan emosional, diantaranya:

\section{Keterlibatan Mahasiswa}

Secara kognitif, yang termasuk dalam keterlibatan adalah pengetahuan arti akhir tentang konsekuensi penting yang disebabkan oleh penggunaan program. Termasuk juga evaluasi terhadap suatu program. Jika keterlibatan suatu program tinggi, seseorang akan mengalami tanggapan pengaruh yang lebih kuat seperti emosi dan perasaan yang kuat. Keberhasilan akademis dan tingkat keunggulan pengajaran sangat bergantung pada tingkat keterlibatan mahsiswa di kelas. Nampak jelas bahwa pembelajaran konsep esensial dan pengembangan refleksi pada diri mahasiswa akan dipermudah jika program tersebut menarik, menghibur, bermanfaat, bermakna dan penting bagi mereka.

Untuk mencapai tingkat keterlibatan yang tinggi dari mahasiswa saat ini, kita perlu mengetahui cara menggabungkan strategi dan aktivitas yang menarik. Kedua faktor ini, yang terkait dengan keterampilan pelaksanaan program, akan sangat mempengaruhi konsentrasi dan investasi emosional mahasiswa dalam programnya, yang akan berdampak kuat pada hasil yang diperoleh serta pada nilai yang diberikan.

Dapat dikatakan bahwa tingkat keterlibatan yang memuaskan dicapai jika mahasiswa tidak hanya memperhatikan, tetapi juga berinvestasi penuh dalam implementasi programnya. Faktor-faktor seperti partisipasi dalam aktivitas, keterlibatan emosional, motivasi atau kemampuan untuk merasa memiliki program untuk meningkatkan pengalaman mereka merupakan indikasi dari tingkat keterlibatan. Perasaan menjadi bagian dari suatu kelompok atau tujuan program juga dapat mempengaruhi tingkat partisipasi.

\section{Merdeka Belajar-Kampus Merdeka (MBKM)}

Kampus Merdeka merupakan bagian dari kebijakan Merdeka Belajar oleh Kementerian Pendidikan, Kebudayaan, Riset, dan Teknologi Republik Indonesia yang memberikan kesempaatan bagi mahasiswa untuk mengasah kemampuan sesuai bakat dan minat dengan terjun langsung ke dunia kerja sebagai persiapan karier masa depan. Merdeka belajar adalah memberi kebebasan dan otonomi kepada lembaga pendidikan, dan merdeka dari birokratisasi, dosen dibebaskan dari birokrasi vang berbelit serta mahasiswa diberikan kebebasan untuk memilih bidang yang mereka sukai.

Institusi perguruan tinggi dituntut untuk menjalankan Tri Dharma Perguruan Tinggi yang mencakup pendidikan dan pengajaran, penelitian dan pengembangan, serta pengabdian kepada masyarakat. Seiring dengan perkembangan dan tuntutan zaman, perguruan tinggi diharuskan untuk mengaplikasikan Tri Dharma dengan menerapkan kebijakan Merdeka Belajar - Kampus Merdeka (MBKM). Kunci keberhasilan perguruan tinggi dalam mengimplementasikan kebijakan Merdeka Belajar-Kampus Merdeka adalah adanya kurikulum yang adaptif dan mampu menyesuaikan diri dengan perkembangan zaman. Kemudian, perlu adanya 
kolaborasi dan kerja sama antara program studi dengan pihak lain yang dapat mendukung keberhasilan proses pembelajaran mahasiswa.

Kebijakan MBKM dilaksanakan dalam rangka mewujudkan proses pembelajaran di perguruan tinggi yang otonom dan fleksibel sehingga perguruan tinggi dapat merancang dan melaksanakan proses pembelajaran yang inovatif agar mahasiswa dapat meraih capaian pembelajaran mencakup aspek sikap, pengetahuan, dan keterampilan secara optimal. Kebijakan ini juga bertujuan untuk meningkatkan link and match dengan dunia usaha dan dunia industri, serta untuk mempersiapkan mahasiswa dalam dunia kerja sejak awal (Direktur Jenderal Pendidikan Tinggi, 2020). Lebih lanjut kebijakan MBKM bertujuan untuk meningkatkan kompetensi lulusan, baik soft skills maupun hard skills agar lebih siap dan relevan dengan kebutuhan zaman, serta menyiapkan lulusan sebagai pemimpin masa depan bangsa yang unggul dan berkepribadian.

Terdapat beberapa program dalam pelaksanaan Merdeka Belajar-Kampus Merdeka (MBKM), antara lain :

1) Pertukaran Pelajar

2) Magang/Praktik Kerja

3) Asistensi Mengajar di Satuan Pendidikan

4) Penelitian/Riset

5) Proyek Kemanusiaan

6) Kegiatan Wirausaha

7) Studi/Proyek Independen

8) Membangun Desa/Kuliah Kerja Nyata Tematik

\section{Metode Penelitian}

Metode pelaksanaan dalam program penelitian implementasi Kebijakan Merdeka Belajar-Kampus Merdeka (MBKM) yaitu berupa survey populasi (total sampling) yang melibatkan mahasiswa, dan dosen pada program studi pendidikan ekonomi Universitas Pasundan. Menurut Sugiyono (2018, hlm. 17), "metode survei adalah penelitian yang dilakukan pada populasi besar maupun kecil, tetapi data yang dipelajari adalah data dari sampel yang diambil dari populasi tersebut, sehingga ditemukan kejadian- kejadian relatif, distribusi, dan hubungan-hubungan antar variabel sosiologis maupun psikologis".

Pelaksanakan penelitian Merdeka Belajar-Kampus Merdeka dilaksanakan melalui strategi sebagai berikut:

1. Penelitian dampak implementasi MBKM dilaksanakan dengan topik: Assesmen ketercapaian IKU 2 dan IKU 7 melalui pengukuran pengetahuan dan keterlibatan mahasiswa dan dosen dalam MBKM.

2. Pelaksanaan penelitian dampak implementasi MBKM bertujuan untuk mengetahui ketercapaian IKU 2 dan IKU 7 Kepmendikbud 2020.

3. Subjek penelitian dampak implementasi MBKM terdiri dari mahasiswa dan dosen. Mahasiswa meliputi $42,5 \%$ dari seluruh populasi mahasiswa aktif di program studi pendidikan ekonomi Universitas Pasundan. Sementara untuk dosen meliputi $60 \%$ dari seluruh dosen tetap Universitas Pasundan. 
4. Objek penelitian dampak implementasi MBKM adalah pemahaman dan keterlibatan mahasiswa dan dosen dalam program kebijakan MBKM.

5. Penelitian dilaksanakan pada pekan ke-2 hingga ke- 3 bulan Desember 2021.

6. Hasil penelitian didiseminasikan dalam sebuah seminar pada tingkat prodi, fakultas dan perguruan tinggi.

7. Luaran dari penelitian dampak implementasi MBKM berupa:
a. Laporan berupa teks dan video
b. Draft Artikel yang akan dipublikasikan di jurnal nasional terakreditasi
c. Draft Artikel yang akan dipublikasikan di media massa

\section{Hasil dan Pembahasan}

1. Seberapa jauh Saudara mengetahui tentang kebijakan Merdeka BelajarKampus Merdeka (MBKM)? (Pilih salah satu)

\begin{tabular}{lrr}
\hline \multicolumn{1}{c}{ Alternatif Jawaban } & Frekuensi & Persentase \\
\hline Mengetahui kebijakan secara keseluruhan. & 11 & $6,67 \%$ \\
Mengetahui sebagian besar isi kebijakannya. & 79 & $47,88 \%$ \\
Mengetahui sedikit. & 71 & $43,03 \%$ \\
Belum mengetahui sama sekali & 4 & $2,42 \%$ \\
\hline \multicolumn{1}{c}{ Total } & $\mathbf{1 6 5}$ & $\mathbf{1 0 0 \%}$
\end{tabular}

Berdasarkan hasil survey seberapa jauh mahasiswa mengetahui tentang kebijakan Merdeka Belajar- Kampus Merdeka (MBKM), total frekuensi mahasiswa yang memberikan respon sebanyak 165 mahasiswa. Respon terbanyak mahasiswa menjawab mengetahui sebagian besar isi kebijakan dengan 79 atau 47,88\% mahasiswa, sebanyak 71 atau 43,03 mahasiswa memberikan respon jawaban mengetahui sedikit, sebanyak 11 atau $6,67 \%$ mahasiswa memberikan respon jawaban mengetahui kebijakan secara keseluruhan, sedangkan respon terendah mahasiswa menjawab belum mengetahui sama sekali dengan 4 atau 2,42\% mahasiswa. Berdasarkan interpretasi ini, dapat disimpulkan bahwa mahasiswa secara umum telah mengetahui tentang kebijakan MBKM di Program Studi Pendidikan Ekonomi FKIP Universitas Pasundan

2. Menurut saudara, hingga berapa semester dan berapa sks yang dapat disetarakan dengan bentuk kegiatan MBKM di luar Perguruan Tingginya?

\begin{tabular}{|c|c|c|}
\hline Alternatif Jawaban & Frekuensi & Persentase \\
\hline 1 & 37 & $13,17 \%$ \\
\hline 2 & 87 & $30,96 \%$ \\
\hline 3 & 83 & $29,54 \%$ \\
\hline 4 & 74 & $26,33 \%$ \\
\hline Total & 281 & $100 \%$ \\
\hline
\end{tabular}

Berdasarkan hasil survey hingga berapa semester dan berapa sks yang dapat disetarakan dengan bentuk kegiatan MBKM di luar Perguruan Tinggi, total frekuensi mahasiswa yang memberikan respon sebanyak 281 mahasiswa. Respon terbanyak mahasiswa menjawab dua semester dengan 87 atau 30,96\% mahasiswa, sebanyak 83 atau 29,54\% mahasiswa memberikan respon jawaban 
3 semester, sebanyak 74 atau $26,33 \%$ mahasiswa memberikan respon jawaban 4 semester, sedangkan respon terendah mahasiswa menjawab satu semester dengan 37 atau $13,17 \%$ mahasiswa. Berdasarkan interpretasi ini, dapat disimpulkan bahwa mahasiswa Program Studi Pendidikan Ekonomi FKIP Universitas Pasundan secara umum mengetahui jumlah semester dan sks yang dapat disetarakan dengan bentuk kegiatan MBKM di luar Perguruan Tingginya yaitu 2 semester dan 3 semester.

3. Apakah Saudara sudah menyiapkan diri untuk menjadi bagian dalam kegiatan MBKM? (Disesuaikan pilihan masing-masing)

\begin{tabular}{|c|c|c|}
\hline Alternatif Jawaban & Frekuensi & Persentase \\
\hline Tidak Berminat & 1 & $0,61 \%$ \\
\hline Belum & 56 & $33,94 \%$ \\
\hline Sudah & 108 & $65,45 \%$ \\
\hline Total & 165 & $100 \%$ \\
\hline
\end{tabular}

Berdasarkan hasil survey apakah mahasiswa sudah menyiapkan diri untuk menjadi bagian dalam kegiatan MBKM, total frekuensi mahasiswa yang memberikan respon sebanyak 165 mahasiswa. Respon terbanyak mahasiswa menjawab sudah dengan 108 atau $65,45 \%$ mahasiswa, sebanyak 56 atau $33,94 \%$ mahasiswa memberikan respon belum, sedangkan respon terendah mahasiswa menjawab tidak berminat dengan 1 atau $0,61 \%$ mahasiswa. Berdasarkan interpretasi ini, dapat disimpulkan bahwa mahasiswa Program Studi Pendidikan Ekonomi FKIP Universitas Pasundan secara umum sudah menyiapkan diri untuk menjadi bagian dalam kegiatan MBKM.

4. Bagaimana ketertarikan saudara terhadap program MBKM yang diadakan oleh Direktorat Jenderal Pendidikan Tinggi, Riset, dan Teknologi?

\begin{tabular}{lrr}
\hline \multicolumn{1}{c}{ Alternatif Jawaban } & Frekuensi & Persentase \\
\hline Sangat Tertarik & 137 & $83,03 \%$ \\
Biasa saja & 27 & $16,36 \%$ \\
Tidak Tertarik & 1 & $0,61 \%$ \\
\hline \multicolumn{1}{c}{ Total } & $\mathbf{1 6 5}$ & $\mathbf{1 0 0} \%$ \\
\hline
\end{tabular}

Berdasarkan hasil survey tentang bagaimana ketertarikan mahasiswa terhadap program MBKM yang diadakan oleh Direktorat Jenderal Pendidikan Tinggi, Riset, dan Teknologi, total frekuensi mahasiswa yang memberikan respon sebanyak 165 mahasiswa. Respon terbanyak mahasiswa menjawab sangat tertarik dengan 137 atau 83,03\% mahasiswa, sebanyak 27 atau $16,36 \%$ mahasiswa memberikan jawaban biasa saja, sedangkan respon terendah mahasiswa menjawab tidak tertarik dengan 1 atau $0,61 \%$ mahasiswa. Berdasarkan interpretasi ini, dapat disimpulkan bahwa mahasiswa Program Studi Pendidikan Ekonomi FKIP Universitas Pasundan secara umum berpendapat bahwa mahasiswa sangat tertarik pada program MBKM yang diadakan oleh Direktorat Jenderal Pendidikan Tinggi, Riset, dan Teknologi. 
5. Apabila Saudara diminta memilih dari 8 (delapan) bentuk kegiatan pembelajaran di luar program studi, mana yang akan Saudara pilih? (Disesuaikan pilihan masing-masing)

\begin{tabular}{lrr}
\multicolumn{1}{c}{ Alternatif Jawaban } & Frekuensi & Persentase \\
\hline Pertukaran Pelajar & 14 & $8,48 \%$ \\
Magang/Praktik Kerja & 92 & $55,76 \%$ \\
Asistensi Mengajar di Satuan Pendidikan & 27 & $16,36 \%$ \\
Penelitian/Riset & 2 & $1,21 \%$ \\
Proyek Kemanusiaan & 3 & $1,82 \%$ \\
Kegiatan Wirausaha & 15 & $9,09 \%$ \\
Studi/Proyek Independen & 2 & $1,21 \%$ \\
Membangun Desa atau Kuliah Kerja Nyata & 10 & $6,06 \%$ \\
Tematik (KKNT) & & $\mathbf{1 0 0 \%}$ \\
\hline \multicolumn{1}{c}{ Total } & $\mathbf{1 6 5}$ & \\
\hline
\end{tabular}

Berdasarkan hasil survey apabila mahasiswa diminta memilih dari 8 (delapan) bentuk kegiatan pembelajaran di luar program studi, mana yang akan mahasiswa pilih, total frekuensi mahasiswa yang memberikan respon sebanyak 165 mahasiswa. Respon terbanyak mahasiswa menjawab Magang/Praktik Kerja dengan 92 atau 55,76\% mahasiswa, sebanyak 27 atau 16,36\% mahasiswa memberikan respon jawaban Asistensi Mengajar di Satuan Pendidikan, sebanyak 15 atau 9,09\% mahasiswa memberikan respon jawaban kegiatan wirausaha, sebanyak 14 atau $8,48 \%$ mahasiswa memberikan respon jawaban pertukaran pelajar, sebanyak 10 atau $6,06 \%$ mahasiswa memberikan respon jawaban Membangun Desa atau Kuliah Kerja Nyata Tematik (KKNT), sebanyak 3 atau $1,82 \%$ mahasiswa memberikan respon jawaban proyek kemanusiaan, sedangkan respon terendah mahasiswa menjawab penelitian/riset dan Studi/Proyek Independen dengan 2 atau 1,21\% mahasiswa. Berdasarkan interpretasi ini, dapat disimpulkan bahwa mahasiswa Program Studi Pendidikan Ekonomi FKIP Universitas Pasundan secara umum bentuk kegiatan MBKM yang dipilih mahasiswa adalah magang atau praktik kerja.

\section{Penutup}

Merdeka Belajar-Kampus Merdeka merupakan salah satu kebijakan dari Menteri Pendidikan dan Kebudayaan. Kebijakan Merdeka Belajar-Kampus Merdeka diharapkan dapat menjadi jawaban atas tuntutan tersebut. Kebijakan tersebut dapat diartikan sebagai bentuk pemberian kebebasan secara otonom kepada lembaga pendidikan dan merdeka dari birokrasi yang terlalu panjang dan kebebasan bagi mahasiswa memilih program yang diinginkan (Direktorat Jenderal Pendidikan Tinggi Kemendikbud RI, 2020). Tujuan besar yang ingin dicapai oleh Kementerian Pendidikan dan Kebudayaan Riset dan Teknologi (Kemdikbud Ristek) adalah terciptanya kultur lembaga pendidikan yang otonom, tidak birokratis, dan terciptanya sistem pembelajaran yang inovatif berbasis pada peminatan dan tuntutan dunia modern. Kebijakan ini telah membuka harapan besar bagi Perguruan Tinggi untuk mampu berkembang dengan cepat dan mampu mengembangkan mutu institusi. 
Program Studi Pendidikan Ekonomi Fakultas Keguruan dan IImu Pendidikan Universitas Pasundan berupaya turut serta bersama pemerintah untuk meningkatkan kompetensi lulusan, baik soft skills maupun hard skills, agar lebih siap dan relevan dengan kebutuhan zaman, menyiapkan lulusan sebagai pemimpin masa depan bangsa yang unggul dan berkepribadian.

Survey pemahaman dan keterlibatan mahasiswa dan dosen dalam program kebijakan merdeka belajar kampus merdeka di program studi pendidikan ekonomi FKIP Universitas Pasundan dijadikan sebagai bentuk evaluasi oleh program studi untuk meningkatkan kualitas pelaksanaan Merdeka Belajar yang akan ditindak lanjuti dalam bentuk persiapan, pelayanan maupun pelaksanaan program MBKM selanjutnya.

Hasil survey menunjukan secara umum mahasiswa memahami program kebijakan merdeka belajar kampus merdeka di program studi pendidikan ekonomi FKIP Universitas Pasundan, hal ini ditunjukan dengan rata-rata jawaban mahasiswa tentang setiap item pertanyaan dalam survey menunjukan respon sesuai dengan indikator jawaban yang disediakan.

Sementara hasil survey untuk dosen menunjukan secara umum mahasiswa memahami program kebijakan merdeka belajar kampus merdeka di program studi pendidikan ekonomi FKIP Universitas Pasundan, hal ini ditunjukan dengan rata-rata jawaban dosen tentang setiap item pertanyaan dalam survey menunjukan respon sesuai dengan indikator jawaban yang disediakan.

Berdasarkan hasil analisis data yang telah dilaksanakan oleh peneliti mengenai survey pemahaman dan keterlibatan mahasiswa dan dosen dalam program kebijakan merdeka belajar kampus merdeka di program studi pendidikan ekonomi fkip universitas pasundan, maka dapat disimpulkan :

1. Pemahaman mahasiswa dan dosen mengenai program kebijakan merdeka belajar-kampus merdeka sudah baik. Terlihat dari hasil survey yang dilakukan sebagian besar mahasiswa dan dosen sudah mengetahui mengenai program yang ada dalam MBKM tersebut, diantaranya Pertukaran Pelajar, Magang/Praktik Kerja, Asistensi Mengajar di Satuan Pendidikan, Penelitian/Riset, Proyek Kemanusiaan, Kegiatan Wirausaha, Studi/Proyek Independen dan Membangun Desa/Kuliah Kerja Nyata Tematik. Sosialisasisosialisasi mengenai kebjakan MBKM, baik sosialisasi di lingkungan Perguruan Tinggi, atau di Kemendikbud berjalan sangat baik. Hasil tersebut juga merupakan peluang bagi Program Studi untuk terus meningkatkan keterlibatan mahasiswa dan dosen dalam berbagai bentuk kegiatan MBKM.

2. Keterlibatan mahasiswa dan dosen dalam program kebijakan merdeka belajar-kampus merdeka sudah baik. Terlihat dari hasil survey yang dilakukan sebagian besar mahasiswa sudah terlibat dalam program yang ada dalam MBKM, antara lain program kampus mengajar serta pertukaran pelajar. Sementara untuk para dosen di lingkungan program studi sudah terlibat dalam pelaksanaan diskusi dalam pengimplementasian MBKM serta terlibat dalam pelaksanaan pertukaran pelajar sebagai dosen pengampu mata kuliah.

\section{Daftar Pustaka}


UU No 12 tahun 2012 Tujuan Pendidikan Tinggi

Permendikbud Nomor 3 Tahun 2020 tentang Standar Nasional Pendidikan Tinggi

Dimas (2019)

Ahmad Susanto 92018) Bimbingan dan Konseling di Sekolah. Jakarta:

Kencana.Abdurrifqi (2018) Kesulitan Siswa dalam Menyelesaikan Soal Operasi Hitung Bentuk Aljabar Berdasarkan Teori Pemahaman Skemp pada

Kelas VIII A di SMP Negeri 3 Kertak Hanyar. Skripsi, Tarbiyah dan Keguruan.

Syahraeni (2016) Analisis Tingkat Pemahaman Mahasiswa Jurusan IImu

Perpustakaan Fakultas Adab dan Humaniora UIN Alauddin Makassar

Terhadap Sistem Klasifikasi DDC. Undergraduate (S1) thesis, Universitas

Islam Negeri Alauddin Makassar.

Direktur Jenderal Pendidikan Tinggi, 2020

Sugiyono (2018), Metode Penelitian Pendidikan Pendekatan Kuantitatif,. Kualitatif, dan R\&D. Bandung: Alfabeta. 